\title{
EFFECTS OF THE VENOM OF THE BROWN BULLHEAD CATFISH (AMEIURUS NEBULOSUS) ON ISOLATED SMOOTH MUSCLES
}

\author{
Loránd Barthó, ${ }^{1 *}$ Zsolt SÁndor $^{1}$ and Timea BenCSIK ${ }^{2}$ \\ ${ }^{1}$ Department of Pharmacology, Faculty of Medicine, University of Pécs, \\ Szigeti út 12, H-7624 Pécs, Hungary \\ 2Department of Pharmacognosy, Faculty of Pharmacy, University of Pécs, \\ Rókus u. 2, H-7624 Pécs, Hungary
}

(Received: December 5, 2017; accepted: March 19, 2018)

\begin{abstract}
Aqueous extract of the spines of the brown bullhead catfish (Ameiurus nebulosus Lesueur, 1819) caused contraction of the guinea-pig small intestine in vitro, a widely-used preparation in pharmacology. The action is dependent on extracellular $\mathrm{Ca}^{2+}$, and probably takes place on the smooth muscle cells. Mouse gastrointestinal preparations were also contracted by the extract. Stings by the spines of this fish species causes a painful sensation in man. We tested the effect of an extract of spines in isolated organ experiments on innervated smooth muscle preparations. In the guinea-pig ileum, the response to the extract was abolished by the $\mathrm{Ca}^{2+}$-channel blocker nifedipine, but only slightly reduced by atropine (a muscarine receptor antagonist) or tetrodotoxin (TTX; a blocker axonal conduction) or antagonists for $\mathrm{P}_{2 \mathrm{X}}$ purinoceptors. Blocking of serotonin or histamine $\mathrm{H}_{1}$ receptors, tachykinin $\mathrm{NK}_{1}$ receptors, functional impairment of capsaicin-sensitive sensory nerve endings or inhibition of cyclo-oxygenases failed to influence the contractile effect of the extract. No inhibitory action of the extract was detected on the ileum subject to electrical motor nerve stimulation.
\end{abstract}

Keywords: Brown bullhead catfish - venom - smooth muscle effects

\section{INTRODUCTION}

The effects and mechanism of action of the venom of the brown bullhead catfish (Ameiurus nebulosus) was studied on innervated smooth muscle preparations. This fish has been introduced to Hungary in the late 19th century. Here, the subspecies pannonicus has been formed and is widely distributed both in natural waters and ponds or channels. It is well known that this fish can produce painful stings with its stout stings, spines or horns, located adjacent to the dorsal and pectoral fins. The character of pain caused by the stings is indicative of the presence of venom, not only mechanical injury. The venom of a related fish species (Ictalurus catus) has been analyzed [9]. The fraction toxic to mice has been found to be heat-resistant and not destroyed by trypsin, in spite of a high estimated molecular weight (around $10,000)$ [9]. Catfish stings are usually harmless to human beings, but occasionally complications may occur [6]. Effects of stings of ictalurid catfishes (Schilbeoides

\footnotetext{
*Corresponding author; e-mail address: lorand.bartho@aok.pte.hu
} 
exilis and S. leptanthus, Ictalurus melas and I. punctatus) on test fish have been studied [5], but the tests performed were quite different from those of the current study. The aim of our experiments was to investigate the biological effects of an aqueous extract of spines of Ameiurus nebulosus (ssp. pannonicus) in isolated organ experiments on the isolated small intestine of the guinea-pig, a tissue containing smooth muscle and nerves and a most widely-used and thoroughly-characterized preparation in experimental pharmacology (see Table 1). Gastrointestinal preparations of the mouse were also used.

\section{MATERIALS AND METHODS}

The experiments have been approved by the Regional Committee for Animal Research, as well as by the respective committee of University of Pécs. These experiments were of the "ex vivo" type and are in accordance with the European Guidelines on Laboratory Animal Care.

One-year old brown bullhead fish were used. They were kept in an aquarium for nearly 1 year (from a size of a few $\mathrm{mm}$ ) and now weighed $14 \mathrm{~g}$ on average. They were fed on standard food for aquarium fish (granulated high-value fish food plus dried Daphnia). Fish were killed by a strong blow to the head. All three spines were removed, soaked in Krebs solution ( $50 \mathrm{mg}$ wet tissue/ml solution) for $10 \mathrm{~min}$ at room temperature, with intermittent vortexing. The tissue was then removed from the solution (that will hereafter be called extract). Samples of the extract were pooled to make a $10 \mathrm{ml}$ stock solution, then divided into $100 \mu \mathrm{l}$ samples and kept at $-20{ }^{\circ} \mathrm{C}$. An extract of the abdominal fins was prepared in the same way.

Guinea-pigs (short-haired, coloured) of either sex, weighing 450-580 g were stunned by a blow to the occiput and bled out. Whole segments of the ileum (approximately $2 \mathrm{~cm}$ in length) were suspended in organ baths containing $7 \mathrm{ml}$ of oxygenated $\left(95 \% \mathrm{O}_{2}, 5 \% \mathrm{CO}_{2}\right) \mathrm{Krebs}-$ Henseleit solution at $37{ }^{\circ} \mathrm{C}$. Longitudinal movements were recorded auxotonically, using Experimetria (Budapest) force transducers and bridge amplifiers. The transducers were fitted with fine springs for allowing the tissue to contract. The initial load was $6 \mathrm{mN}$. All experiments commenced after $40 \mathrm{~min}$ equilibration period. A maximum of 2 preparations from the same animal were used for a given type of experiment. Some preparations were electrically field stimulated [27]; cholinergic „twitch” responses elicited by single electrical pulses with 20 min intervals, delivered through a pair of ring electrodes. Parameters of the pulses were $30 \mathrm{~V} / \mathrm{cm}$ amplitude and $0.1 \mathrm{~ms}$ pulse width. The spectrum of detection of the guineapig ileal preparation is given in Table 1.

Adult female C57 mice were killed by a strong blow to the head. Ileum (whole ileum segments in the longitudinal direction) and gastric fundus preparations were set up as described above, with a resting tone of $5 \mathrm{mN}$. Each stomach yielded one single fundus preparation, in which the isolated gastric fundus was opened along both the lesser and the greater curvatures. Contractions to $2 \mu \mathrm{l} / \mathrm{ml}$ of the extract were reproducible (contact times, $3 \mathrm{~min}$ with the ileum and 6-8 $\mathrm{min}$ for the fundus), provided that a 
Table 1

Spectrum of detection of the guinea-pig ileum tests

\begin{tabular}{|c|c|c|c|}
\hline No. & Tests & Activities detected by the test & $\begin{array}{l}\text { Selected } \\
\text { references }\end{array}$ \\
\hline 1 & $\begin{array}{l}\text { Guinea-pig ileum at } \\
\text { basal tone: contrac- } \\
\text { tors via nerve stimu- } \\
\text { lation }\end{array}$ & $\begin{array}{l}\text { Ganglionic stimulants; serotonin (to a greater extent); } \\
\text { cholecystokinin-like drugs, tachykinin } \mathrm{NK}_{3} \text { receptor agonists, } \\
\mathrm{P}_{2 \mathrm{x}} \text { purinoceptor agonists (like } \alpha, \beta \text {-methylene ATP), VIP, } \\
\text { PACAP, CGRP, some eicosanoids, endocannabinoids }\end{array}$ & $\begin{array}{l}4,7,8,11 \\
16,17 \\
19-21,22 \\
25,32\end{array}$ \\
\hline 2 & $\begin{array}{l}\text { Guinea-pig ileum at } \\
\text { basal tone: contrac- } \\
\text { tors via smooth mus- } \\
\text { cle stimulation }\end{array}$ & $\begin{array}{l}\text { Muscarinic receptor agonists, histamine (at } \mathrm{H}_{1} \text { receptors), } \\
\text { serotonin (to a lesser extent), tachykinins (substance } \mathrm{P} \text {, } \\
\text { neurokinin } \mathrm{A} \text {, through } \mathrm{NK}_{1} \text { and } \mathrm{NK}_{2} \text { receptors), some other } \\
\text { polypeptides, mast cell activators; spasmogenic effect by } \\
\text { unidentified mechanisms }\end{array}$ & $\begin{array}{l}1,7,8,12, \\
18,23\end{array}$ \\
\hline 3 & $\begin{array}{l}\text { Guinea-pig ileum, } \\
\text { contractions due to } \\
\text { electrical field stimu- } \\
\text { lation of cholinergic } \\
\text { nerves }\end{array}$ & 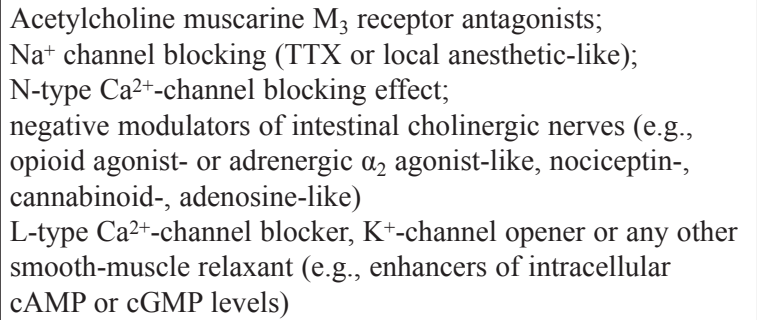 & $\begin{array}{l}10,13,15, \\
24,26,28, \\
29,31\end{array}$ \\
\hline
\end{tabular}

40 min washout period was allowed to the preparations (Table 3). Part of the preparations received TTX $(0.5 \mu \mathrm{M}) 20 \mathrm{~min}$ before the second exposure to the extract.

Drugs used were apamin, atropine sulfate, capsaicin, histamine dihydrochloride, indomethacin, pyridoxalphosphate-6-azophenyl-2',4'-disulphonic acid (PPADS), serotonin creatinin sulfate, tetrodotoxin (TTX; Sigma), ATP, $\alpha, \beta$-methyleneATP, $(2 S, 3 S)-N$-(2-methoxyphenyl)methyl-2-diphenylmethyl-1-azabicyclo[2.2.2] octan-3amine (CP 96345), methysergide, nifedipine, (1-butyl-4-piperidinyl)methyl-8-amino7-chloro-1,4-benzodioxane-5-carboxylate (SB 204070 ), suramin, tropisetron, 1,2,3,6-tetrahydro-1,3-dimethyl-N-[4-(1-methylethyl)phenyl]-2,6-dioxo-7H-purine7-acetamide, 2-(1,3-dimethyl-2,6-dioxo-1,2,3,6-tetrahydro-7H-purin-7-yl)-N(4-isopropylphenyl)acetamide (HC 030031, Tocris), chloropyramine hydrochloride (Egis Pharma, Hungary).

\section{RESULTS}

The extract showed contractile activity on the guinea-pig ileum (Fig. 1A). Concentration-dependence was found with 0.5 or $5 \mu \mathrm{l}$ extract $/ \mathrm{ml}$ bath fluid, which resulted in contractions of $38.3 \pm 2.9$ and $74.1 \pm 5.0 \%(n=4)$, respectively, of the maximal spasm evoked by histamine $(10 \mu \mathrm{M})$. One $\mu \mathrm{l} / \mathrm{ml}$ of the extract was used for pharmacological analysis. Contractions were quick in onset, reached their maximum 
within $0.5 \mathrm{~min}$ and showed only a moderate tendency to decline during the $3 \mathrm{~min}$ observation period. If an interval of $40 \mathrm{~min}$ was allowed to the preparations as washout time, the responses to $1 \mu \mathrm{l} / \mathrm{ml}$ extract were reproducible (Table 2). Pretreatments that partially diminished responses to exposure to the extract were the $\mathrm{Na}^{+}$channel blocker TTX, the muscarinic acetylcholine receptor antagonist atropine, or a combination of the two $\mathrm{P}_{2}$ purinoceptor antagonists PPADS and suramin. The $\mathrm{Ca}^{2+}$ channel blocker nifedipine abolished the response (Table 2). The effect of the extract was not inhibited by the histamine $\mathrm{H}_{1}$ receptor antagonist chloropyramine, a combination of serotonin receptor antagonists, the tachykinin $\mathrm{NK}_{1}$ receptor antagonist $\mathrm{CP} 96345$, the cyclooxygenase inhibitor indomethacin, and capsaicin desensitization (Table 2). The $\mathrm{TRPA}_{1}$ receptor/channel inhibitor $\mathrm{HC} 030031$ slightly, while the $\mathrm{Ca}^{2+}$ sensitive, small conductance $\mathrm{K}^{+}$channel blocker apamin moderately enhanced the response to the extract (Table 2).

Table 2

Effect of the fish spine extract ( $1 \mu \mathrm{l} / \mathrm{ml}$ bath fluid) on the guinea-pig isolated small intestine

\begin{tabular}{|c|c|c|c|}
\hline Pretreatment & $\begin{array}{c}\text { Contraction } \\
(\% \text { of maximum })\end{array}$ & $\begin{array}{l}\text { Contact time } \\
\text { of pretreatment }\end{array}$ & \\
\hline $\begin{array}{l}\text { 1st administration: no pretreatment } \\
\text { 2nd administration: no pretreatment }\end{array}$ & $\begin{array}{l}49.8 \pm 2.7 \\
53.6 \pm 2.9\end{array}$ & & $\mathrm{n}=14$ \\
\hline $\begin{array}{l}\text { 1st: control (solvent: saline) } \\
\text { 2nd: tetrodotoxin }(0.5 \mu \mathrm{M})\end{array}$ & $\begin{array}{c}53.9 \pm 2.4 \\
42.6 \pm 2.6^{*}\end{array}$ & $20 \mathrm{~min}$ & $\mathrm{n}=10$ \\
\hline $\begin{array}{l}\text { 1st: control (solvent: saline) } \\
\text { 2nd: atropine }(0.5 \mu \mathrm{M})\end{array}$ & $\begin{array}{c}46.9 \pm 5.0 \\
41.2 \pm 5.7^{*}\end{array}$ & $20 \mathrm{~min}$ & $\mathrm{n}=8$ \\
\hline $\begin{array}{l}\text { 1st: control (solvent: saline) } \\
\text { 2nd: chloropyramine }(0.3 \mu \mathrm{M})\end{array}$ & $\begin{array}{l}51.3 \pm 4.9 \\
53.0 \pm 5.4\end{array}$ & $20 \mathrm{~min}$ & $\mathrm{n}=7$ \\
\hline $\begin{array}{l}\text { 1st: control (solvent: saline) } \\
\text { 2nd: PPADS }(50 \mu \mathrm{M})+\text { suramin }(100 \mu \mathrm{M})\end{array}$ & $\begin{array}{c}54.7 \pm 4.8 \\
41.8 \pm 5.01 *\end{array}$ & $30 \mathrm{~min}$ & $\mathrm{n}=8$ \\
\hline $\begin{array}{l}\text { 1st: control (solvents: DMSO) } \\
\text { 2nd: serotonin receptor antagonists }{ }^{\#}\end{array}$ & $\begin{array}{l}52.1 \pm 7.8 \\
55.9 \pm 4.2\end{array}$ & $20 \mathrm{~min}$ & $\mathrm{n}=7$ \\
\hline $\begin{array}{l}\text { 1st: control (solvent: alcohol) } \\
\text { 2nd: nifedipine }(1 \mu \mathrm{M})\end{array}$ & $\begin{array}{l}50.3 \pm 5.2 \\
5.1 \pm 2.1^{*}\end{array}$ & $20 \mathrm{~min}$ & $\mathrm{n}=7$ \\
\hline $\begin{array}{l}\text { 1st: control (solvent: DMSO) } \\
\text { 2nd: CP } 96345(1.5 \mu \mathrm{M})\end{array}$ & $\begin{array}{l}52.2 \pm 2.4 \\
40.9 \pm 3.9 \\
\end{array}$ & $45 \mathrm{~min}$ & $\mathrm{n}=8$ \\
\hline $\begin{array}{l}\text { 1st: control (solvent: saline) } \\
\text { 2nd: apamin }(0.1 \mu \mathrm{M})\end{array}$ & $\begin{array}{l}46.3 \pm 3.0 \\
65.9 \pm 4.7^{*}\end{array}$ & $20 \mathrm{~min}$ & $\mathrm{n}=6$ \\
\hline $\begin{array}{l}\text { 1st: control: (solvent: alcohol) } \\
\text { 2ns: indomethacin }(5 \mu \mathrm{M})\end{array}$ & $\begin{array}{l}44.1 \pm 5.5 \\
38.8 \pm 4.5\end{array}$ & $45 \mathrm{~min}$ & $\mathrm{n}=7$ \\
\hline $\begin{array}{l}\text { 1st: control (solvent: alcohol) } \\
\text { 2nd: capsaicin desensitization \#\# }\end{array}$ & $\begin{array}{l}45.1 \pm 3.1 \\
54.0 \pm 6.5\end{array}$ & (see below) & $\mathrm{n}=6$ \\
\hline $\begin{array}{l}\text { 1st: control (solvent: DMSO) } \\
\text { 2nd: HC } 030031(30 \mu \mathrm{M})\end{array}$ & $\begin{array}{c}47.9 \pm 2.4 \\
54.8 \pm 1.7^{*}\end{array}$ & $30 \mathrm{~min}$ & $\mathrm{n}=8$ \\
\hline
\end{tabular}

\#Methysergide $\left(0.3 \mu \mathrm{M}\right.$, predominantly inhibiting 5 - $\mathrm{HT}_{2}$ receptors, dissolved in saline), tropisetron $(3 \mu \mathrm{M}$, for $5-\mathrm{HT}_{3}$ receptors, dissolved in saline) and SB 204070 ( $3 \mu \mathrm{M}$, for $5-\mathrm{HT}_{4}$ receptors, dissolved in DMSO). \#Capsaicin, $10 \mu \mathrm{M}$ for $10 \mathrm{~min}$, followed by $60 \mathrm{~min}$ washout period.

Main \pm s.e.m. are shown. *denotes statistically significant differences from the solvent-treated responses (Wilcoxon test). 


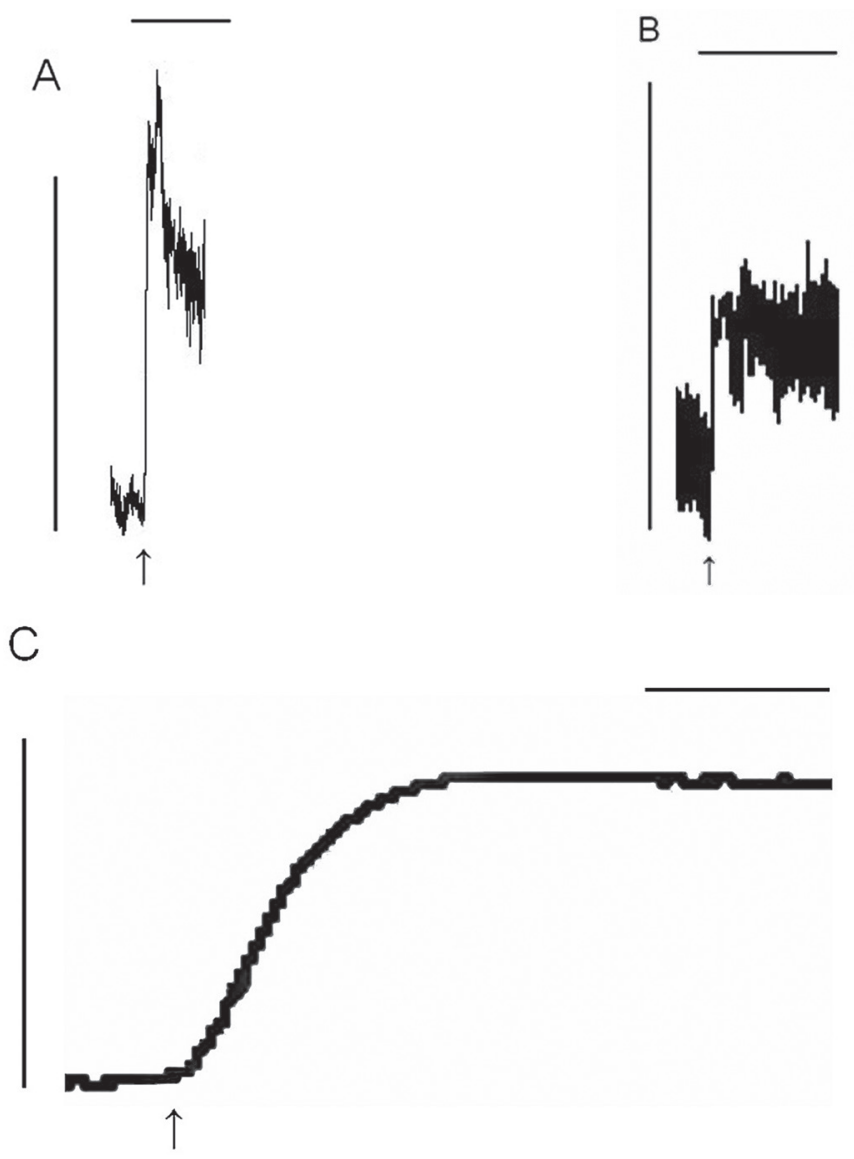

Fig. 1. Original tracings showing the contractile effects of the catfish spine extract (added at the arrow) on the guinea-pig ileum (A; $1 \mu \mathrm{l} / \mathrm{ml}$ extract), mouse ileum (B; $2 \mu \mathrm{l} / \mathrm{ml}$ extract) and mouse gastric fundus strip (C; $2 \mu \mathrm{l} / \mathrm{ml}$ extract). Calibrations, vertical: $50 \%$ of maximal contraction to histamine $(10 \mu \mathrm{M}, \mathrm{A})$ or acetylcholine $(10 \mu \mathrm{M}, \mathrm{B}, \mathrm{C})$; horizontal: $3 \mathrm{~min}$

Two concentrations of the extract $(0.25$ and $1 \mu \mathrm{l} / \mathrm{ml})$ were added while the preparations were field stimulated. The smaller concentration enhanced the amplitude of the cholinergic "twitch" response, with only a small and transient elevation of the baseline, while the larger one elevated the baseline without modifying the "twitch" response throughout the $15 \mathrm{~min}$ observation period $(\mathrm{n}=4$ each). No inhibitory effect was seen whatsoever, which indicates that mechanisms listed in Table 1, row 3 are not activated by the extract.

An extract of the abdominal fins $(2 \mu 1 / \mathrm{ml})$ had practically no effect on the ileum ( $0-6 \%$ contraction, $1.2 \%$ on average, $n=5)$.

Positive contols from previous and the current experiments in the ileum for the inhibitors (in the concentrations used) were as follows. TTX and atropine practically 
abolish half-maximal, cholinergic „twitch" responses to electrical stimulation; chloropyramine blocks near-maximal contractions to histamine $(0.1 \mu \mathrm{M})$, without inhibiting the "twitch" contraction; PPADS + suramin suppresses contractions to ATP (300 $\mu \mathrm{M})$ or $\alpha, \beta$-methyleneATP $(10 \mu \mathrm{M})$; nifedipine $(1 \mu \mathrm{M})$ blocks half-maximal contractions to exogenous acetylcholine or histamine (also the cholinergic „twitch”); the combination of serotonin receptor antagonists blocks near-maximal ileum contractions to serotonin $(0.3-1 \mu \mathrm{M})$; the tachykinin $\mathrm{NK}_{1}$ receptor antagonist $\mathrm{CP} 96345$ (1.5 $\mu \mathrm{M})$ causes an approximately 30 -fold shift to the right of concentration-response curves for substance P (0.3-6 nM). Capsaicin desensitization blocks all effects of acute capsaicin administration $(0.3-1 \mu \mathrm{M})$. These results were obtained on 3-10 preparations and partly served as confirmation of data of literature [see 1,3]. To date, we have no positive control for the TRPA1 receptor/channel inhibitor HC 030031 in the guinea-pig ileum, since the putative agonists show conflicting results (unpublished observations).

The extract $(2 \mu \mathrm{l} / \mathrm{ml})$ also contracted the mouse gastric fundus and mouse ileum preparations. The effect of TTX on these responses was similar to that seen in the guinea-pig ileum (Fig. 1B, C; Table 3).

Table 3

Effect of the fish spine extract ( $2 \mu \mathrm{l} / \mathrm{ml}$ bath fluid) on the mouse ileum and stomach fundus strip

\begin{tabular}{|l|c|c|c|}
\hline \multicolumn{1}{|c|}{ Pretreatment } & \multicolumn{1}{c|}{$\begin{array}{c}\text { Contraction } \\
\text { (\% of maximum) }\end{array}$} & $\begin{array}{c}\text { Contact time } \\
\text { of pretreatment }\end{array}$ & \\
\hline \multicolumn{2}{|c|}{ Mouse ileum } & 20 min & $\mathrm{n}=7$ \\
\hline 1st administration: no pretreatment & $26.2 \pm 2.5$ & \\
2nd administration: no pretreatment & $25.0 \pm 2.4$ & & \\
\hline 1st: control (solvent: saline) & $\begin{array}{l}24.4 \pm 2.2 \\
\text { 2nd: tetrodotoxin }(0.5 \mu \mathrm{M})\end{array}$ & & $\mathrm{n}=5$ \\
\hline \multicolumn{2}{|c|}{ Mouse gastric fundus } & $\mathrm{n}=4$ \\
\hline 1st administration: no pretreatment & $47.0 \pm 6.3$ & 20 min & \\
2nd administration: no pretreatment & $50.3 \pm 7.0$ & & \\
\hline 1st: control (solvent: saline) & $45.8 \pm 5.2$ & & \\
2nd: tetrodotoxin $(0.5 \mu \mathrm{M})$ & $49.9 \pm 5.5$ & & \\
\hline
\end{tabular}

Main \pm s.e.m. are shown.

\section{DISCUSSION}

The extract of the spines (but not of the caudal fins) of the brown bullhead catfish caused smooth contraction on the guinea-pig small intestine; no inhibitory action has been detected (e.g., on the field-stimulated ileum). We interpret the results obtained from a pharmacological analysis as follows.

The strongest (practically full) inhibition of the contractile response to the extract was found with the $\mathrm{Ca}^{2+}$ channel blocker nifedipine, which indicates an essential role of voltage-dependent, L-type $\mathrm{Ca}^{2+}$ channels in this response. For comparison, acetyl- 
choline- or histamine-evoked responses of similar size are also strongly inhibited by nifedipine, which points to the involvement of voltage-dependent $\mathrm{Ca}^{2+}$ channels in the course of the Gq-protein-mediated response to these agonists. Whether or not a release of intracellular $\mathrm{Ca}^{2+}$ is also involved in the effect of the extract cannot be decided on the basis of the current study.

Tetrodotoxin and atropine caused a rather slight reduction in the effect of the extract. Given that both pretreatments are able to fully inhibit the "twitch" responses (tetrodotoxin pre- and atropine postjunctionally), the modest effect of these drugs on the response to the extract might be attributed to an overall reduction of the excitability of the preparations, rather than a specific inhibition of the effect of the extract. This indicates that mechanisms, listed in Table 1, 1st row are unlikely to mediate the contraction caused by the extract. The moderate enhancement of the effect of the extract by the $\mathrm{K}^{+}$channel inhibitor apamin [see 1] may also be a result of an overall increase of the excitability of the preparations.

$\mathrm{CP} 96345$ is a tachykinin $\mathrm{NK}_{1}$ receptor antagonist with an $\mathrm{IC}_{50}$ below $100 \mathrm{nM}$ [14]. On the longitudinal muscle of the guinea-pig small intestine the main tachykinin receptor is the $\mathrm{NK}_{1}$ type and the effectiveness of CP $96345(1.5 \mu \mathrm{M})$ against exogenous substance $\mathrm{P}$ was confirmed in the current study. Its failure to inhibit the effect of the extract indicates that a substance P-like peptide is not involved in the contractile effect of the extract. Cyclo-oxygenase products seem not to be involved, as shown by the lack of influence of indomethacin. A mediating role of histamine, serotonin or an ATP-like purinoceptor agonist is improbable, given the lack of influence of chloropyramine (histamine $\mathrm{H}_{1}$ receptor antagonist), or serotonin receptor antagonists, and a modest inhibition by PPADS + suramin, respectively. The lack of inhibitory effect of the extract on the electrically-induced "twitch" contractions of the guinea-pig ileum indicates that no major involvement of smooth muscle-relaxant mediators (e.g., the cGMP enhancer nitric oxide, NO) takes place.

Taken together, these data indicate that the extract acts on the ileum directly on the smooth muscle, in a $\mathrm{Ca}^{2+}$-dependent manner. Yet, a tetrodotoxin-insensitive release of some (unidentified) neurotransmitter from intestinal nerves cannot be fully excluded as mechanism. Although the pharmacological sensitivity of the effect of the extract does not match the excitatory effect of the sensory stimulant drug capsaicin in this preparation [see 3], we found advisable to study the influence of capsaicin desensitization, a procedure that renders capsaicin-sensitive sensory nerve endings functionally inactive, i.e. insensitive not only against capsaicin, but also any type of stimulus, including antidromic electrical stimulation $[2,3,30]$. In spite of the apparent painproducing effect of Ameiurus stings, no involvement of capsaicin-sensitive sensory nerves in the gut-contracting effect of the extract could be verified. This, however, does not exclude other ways of sensory stimulation by the venom. Further studies will be needed for the clarification of this point.

Experiments on mouse preparations yielded rather similar results to those obtained on the guinea-pig gut, also as far as the modest (statistically insignificant) decrease of the response in the presence of TTX. 
In conclusion, the venom of the brown bullhead catfish causes $\mathrm{Ca}^{2+}$-dependent smooth muscle contraction. This effect, as well as the contractile action on mouse preparations seem not to involve $\mathrm{Na}^{+}$-dependent nerve action potentials. As far as the mechanism of this effect is concerned, the roles of a number of important mediators have been excluded. The stimulatory mechanism(s) encountered might contribute to the toxicity and pain produced by the venom.

\section{ACKNOWLEDGEMENTS}

The authors express their thanks to the Faculty of Medicine, University Medical School for providing a postdoctoral grant to Timea Bencsik and supporting this research in other ways as well.

\section{REFERENCES}

1. Alexander, S. P. H., Mathie, A., Peters, J. A. (2011) Guide to receptors and channels. Br. J. Pharmacol. 164, Supplement 1.

2. Barthó, L., Szolcsányi, J. (1978) The site of action of capsaicin on the guinea-pig isolated ileum. Naunyn-Schmiedeb. Arch. Pharmacol. 305, 75-81.

3. Barthó, L., Benkó, R., Patacchini, R., Pethő, G., Holzer-Petsche, U., Holzer, P., Lazar, Z., Undi, S., Illenyi, L., Antal, A., Horváth, Ö. P. (2004) Effects of capsaicin on visceral smooth muscle: a valuable tool for sensory neurotransmitter identification. Eur. J. Pharmacol. 500, 143-157.

4. Benkó, R., Undi, S., Wolf, M., Barthó, L. (2005) Effects of acute administration of and tachyphylaxis to $\alpha, \beta$-methyleneATP in the guinea-pig small intestine. Basic Clin. Pharmacol. Toxicol. 97, 369-373.

5. Birkhead, W. S. (1967) The comparative toxicity of stings of the ictalurid catfish genera Ictalurus and Schilbeoides. Comp. Biochem. Physiol. 22, 101-111.

6. Blomkalns, A. L., Otten, E. J. (1999) Catfish spine envenomation: a case report and literature review. Wilderness Environ. Med. 10, 242-246.

7. Bortoff, A. (1972) Digestion: motility. Annu. Rev. Physiol. 34, 261-290.

8. Brodde, O. E. (1990) 5-Hydroxytryptamine-receptor subtypes. Clin. Physiol. Biochem. 8, Suppl 3, $19-27$.

9. Calton, G. J., Burnett, J. W. (1975) Catfish (Ictalurus catus) fin venom. Toxicon 13, 399-403.

10. Chung, S. S., Ahn, D. S., Lee, H. G., Lee, Y. H., Nam, T. S. (2005) Inhibition of carbachol-evoked oscillatory currents by the $\mathrm{NO}$ donor sodium nitroprusside in guinea-pig ileal myocytes. Exp. Physiol. 90, 577-586.

11. Dékány, A., Benkó, R., Szombati, V., Barthó, L. (2013) The contractile effect of anandamide in the guinea-pig small intestine is mediated by prostanoids but not TRPV1 receptors or capsaicin-sensitive nerves. Basic Clin. Pharmacol. Toxicol. 112, 341-345.

12. Ehlert, F. J., Sawyer, G. W., Esqueda, E. E. (1999) Contractile role of $\mathrm{M}_{2}$ and $\mathrm{M}_{3}$ muscarinic receptors in gastrointestinal smooth muscle. Life Sci. 64, 387-394.

13. Gustafsson, L., Hedqvist, P., Fredholm, B. B., Lundgren, G. (1978) Inhibition of acetylcholine release in guinea pig ileum by adenosine. Acta Physiol. Scand. 104, 469-478.

14. Hakanson, R., Wang, Z. Y., Folkers, K. (1991) Comparison of spantide II and CP-96,345 for blockade of tachykinin-evoked contractions of smooth muscle. Biochem. Biophys. Res. Commun. 178, 297301

15. Harry, J. (1962) Effect of cooling, local anaesthetic compounds and botulinum toxin on the responses of and the acetylcholine output from the electrically transmurally stimulated isolated guinea-pig ileum. Br. J. Pharmacol. Chemother. 19, 42-55. 
16. Hayashi, E., Yamada, S., Mori, M. (1977) Comparative studies on anti-nicotinic action of hexamethonium, mecamylamine and adenosine in the guinea pig isolated ileum. Jpn. J. Pharmacol. 27, 659665.

17. Holzer, P., Barthó, L., Matusak, O., Bauer, V. (1989) Calcitonin gene-related peptide action on intestinal circular muscle. Am. J. Physiol. 256, G546-G552.

18. Holzer, P., Holzer-Petsche, U. (2001) Tachykinin receptors in the gut: physiological and pathological implications. Curr. Opin. Pharmacol. 1, 583-590.

19. Katsoulis, S., Schmidt, W. E., Clemens, A., Schwörer, H., Creutzfeldt, W. (1992) Vasoactive intestinal polypeptide induces neurogenic contraction of guinea-pig ileum. Involvement of acetylcholine and substance P. Regul. Pept. 38, 155-164.

20. Katsoulis, S., Clemens, A., Schwörer, H., Creutzfeldt, W., Schmidt, W. E. (1993) PACAP is a stimulator of neurogenic contraction in guinea pig ileum. Am. J. Physiol. 265, G295-G302.

21. Kosterlitz, H. W., Robinson, J. A. (1958) The inhibitory action of morphine on the contraction of the longitudinal muscle coat of the isolated guinea-pig ileum. Br. J. Pharmacol. Chemother. 13, 296-303.

22. Maggi, C. A., Patacchini, R., Santicioli, P., Theodorsson, E., Meli, A. (1988) Several neuropeptides determine the visceromotor response to capsaicin in the guinea-pig isolated ileal longitudinal muscle Eur. J. Pharmacol. 148, 43-49.

23. Maggi, C. A., Patacchini, R., Meini, S., Quartara, L., Sisto, A., Potier, E., Giuliani, S., Giachetti, A (1994) Comparison of tachykinin $\mathrm{NK}_{1}$ and $\mathrm{NK}_{2}$ receptors in the circular muscle of the guinea-pig ileum and proximal colon. Br. J. Pharmacol. 112, 150-160.

24. North, R. A., Tonini, M. (1977) The mechanism of action of narcotic analgesics in the guinea-pig ileum. Br. J. Pharmacol. 61, 541-549.

25. Patacchini, R., Bartho, L., Holzer, P., Maggi, C. A. (1995) Activity of SR 142801 at peripheral tachykinin receptors. Eur. J. Pharmacol. 278, 17-25.

26. Paton, W. D .M. (1957) The action of morphine and related substances on contraction and on acetyl choline output of coaxially stimulated guinea-pig ileum. Br. J. Pharmacol. Chemother. 12, 119-127.

27. Paton, W. D .M., Vizi, E. S. (1969) The inhibitory action of noradrenaline and adrenaline on acetylcholine output by guinea-pig ileum longitudinal muscle strip. Br. J. Pharmacol. 35, 10-20.

28. Pertwee, R. G. (2001) Cannabinoids and the gastrointestinal tract. Gut 48, 859-867.

29. Sun, Y. D., Benishin, C. G. (1995) Effects of calcitonin gene-related peptide on cyclic AMP production and relaxation of longitudinal muscle of guinea pig ileum. Peptides 16, 293-297.

30. Szolcsányi, J., Barthó, L. (1978) New type of nerve-mediated cholinergic contractions of the guineapig small intestine and its selective blockade by capsaicin. Naunyn-Schmiedeb. Arch. Pharmacol. 305, 83-90.

31. Vizi, E. S. (1979) Presynaptic modulation of neurochemical transmission. Prog. Neurobiol. 12 $181-290$

32. Vizi, E. S., Bertaccini, G., Impicciatore, M., Knoll, J. (1973) Evidence that acetylcholine release by gastrin and related polypeptides contributes to their effect on gastrointestinal motility. Gastroenterology 64, 268-277. 